\title{
Lords warn industry and government to back science changes
}

London. A committee of Britain's House of Lords has warned the government that the benefits of last year's white paper (policy document) on the organization of science will materialize only if both industry and government do more to support a 'partnership' with the research community.

The report - from the Lords' Select Committee on Science and Technology is being published one week after the Department of Trade and Industry (DTI) announced that it has abolished the post of chief scientific adviser. Under a reorganization taking effect on 1 March, scientific issues will be dealt with by the revamped industrial sponsorship division, and the department will concentrate its support for innovation on projects such as regional technology advice centres.

Lord Flowers, the chairman of the select committee (and a former chairman of the Science and Engineering Research Council), says that he has not been told of the reasons for the DTI's decision. But he admits that it appears to go "in the opposite direction" from what the committee is advocating.

"Until I have had a satisfactory explanation, I cannot help but regard the event as the re-

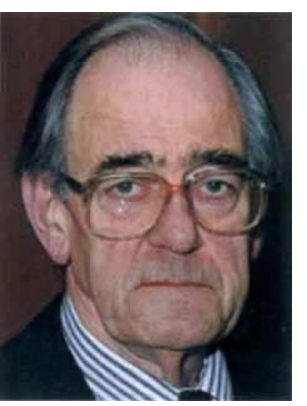
Lord Flowers moval of an office which forms a natural public focus for science and technology activities within a very important part of the government," says Flowers. "I cannot see the logic of it."

The committee's report welcomes the general thrust of the white paper in the need for the research community to focus more clearly on the priorities of British industry. It also applauds the appointment of a single individual responsible to the minister for running the six research councils, an innovation close to some of the committee's own proposals in the past for a single research council.

But it claims that, while the scientific community has been striving to build a partnership with industry for some time, there has been an inadequate response from the 'user' side. Flowers points to the relatively low level of investment in civilian research and development by many British companies compared to their overseas competitors, and to the need for their greater involvement in the process of setting the countries long-term technological priorities.

David Dickson

\section{US panel wants global body to control civil plutonium use}

Washington. Plutonium meant for use as nuclear fuel can readily be used for bombmaking, and therefore poses a large and growing proliferation threat, according to a major report published this week by the National Academy of Sciences in Washington (see also page 301).

As a result, the report - which was prepared for the president's National Security Adviser, and is expected to have a strong impact on the Clinton administration's proliferation policy - calls for all civil or reactor-grade plutonium to be brought under a new international regime to prevent its theft or misuse.

The panel, which was chaired by Wolfgang Panofsky, former director of the Stanford Linear Accelerator Centre, also recommends that the United States and Russia should negotiate a new agreement to jointly monitor and control the stockpiles of plutonium and other materials being created by the dismantling of nuclear weapons under arms control agreements.

It argues that the United States should offer immediate assistance to Russia and other former Soviet states to help with security at sites where weapons-grade fissile material is stored, in order to counter the growing risk of theft.

And - in a blow to the Department of Energy's troubled Advanced Liquid Metal Reactor at the Argonne National Laboratory (see Nature 365,$99 ; 1993$ ) - it says that development of new types of nuclear reactor cannot be justified in terms of their potential for disposing of plutonium. Plutonium, it argues, is best burned without reprocessing in existing nuclear power stations, or else stored in glass with other nuclear waste.

One of the clearest messages from the 280-page report, prepared by the academy's Committee on International Security and Arms Control (CISAC), concerns the looming danger of civil grade plutonium being used for bomb-making.

"Reactor grade plutonium can be used to make nuclear weapons," says the committee's chairman, John Holdren of the University of California, Berkeley. "Our report is quite explicit about, firstly, its usability in weapons, and, secondly, its extractability from spent nuclear fuel."

The report explains how problems about using reactor grade plutonium can be overcome by weapons designers, and warns that the extraction of such plutonium from spent nuclear fuel becomes easier as the fuel ages, multiplying proliferation risks.

It calls for "consideration of more proliferation-resistant nuclear fuel cycles", and although it does not make any direct recommendation on THORP, the huge nuclear fuel recycling facility due to start up in Britain later this year, it could make an impact on the debate in Britain.

"There is currently no economic case [for recycling]," says Holdren. "We make that clear, so we may have some impact on THORP because it will be harder for anyone to argue that it has an economic rationale."

In two month's time, the academy will report in more detail on reactor options for disposing of weapons plutonium, and a report on dealing with spent nuclear fuel will appear later in the year. Colin Macilwain

\section{Praise for Rutherford as its future is debated}

London. Britain's largest government research facility, the Rutherford Appleton Laboratory, still provides 'state of the art' facilities despite a reduction of onethird in research council funding over the past five years. But a National Audit Office (NAO) survey found that in some cases demand for its services is three times what the laboratory can supply.

The government's watchdog body found the laboratory had successfully increased its external funding as direct grants from the Science and Engineering Research Council (SERC) had dropped, and had managed to maintain high standards. About 70 per cent of respondents to the NAO survey said that the laboratory had been "absolutely vital" or at least "very important" in achieving their research objectives.

Staff at the laboratory came across as helpful, responsive and knowledgeable "beyond the call of duty". One respondent described them as "overworked and underpaid", and overall 95 per cent of respondents said they found facility staff good or excellent.

The main complaint was about lack of resources. Of the four key facilities, ISIS, the world's most powerful source of pulsed neutrons, came off worst, with 45 per cent of users saying competition for time and resources meant they had not received all they requested.

The NAO report comes at a time when the future role of the laboratory is under debate. From April, responsibility for the laboratory will transfer from the SERC to the new Engineering and Physical Sciences Research Council (see Nature 366, $100 ; 1993$ ), but a more long-term shakeup is anticipated.

Fiona Gammie 